\title{
Salinity-Induced Alterations in the Growth, Membranes and Osmolytes of Musa spp. cv. Caipira (AAA) During Micropropagation
}

\author{
Yuri Lima Melo ${ }^{1}$, Isabele Aragão Gomes Trindade ${ }^{2}$, Monique Cristina Simão Lopes ${ }^{3}$, \\ Cibelley Vanúcia Santana Dantas ${ }^{3}$, Josemir Moura Maia ${ }^{1}$ \& Cristiane Elizabeth Costa de Macêdo ${ }^{2}$ \\ ${ }^{1}$ Programa de Pós-Graduação em Ciências Agrárias, Universidade Estadual da Paraíba, Campina Grande, Brazil \\ ${ }^{2}$ Departamento de Biologia Celular e Genética, Universidade Federal do Rio Grande do Norte, Natal, Brazil \\ ${ }^{3}$ Programa de Pós-Graduação em Fitotecnia, Universidade Federal Rural do Semi-Árido, Mossoró, Brazil \\ Correspondence: Yuri Lima Melo, Programa de Pós-Graduação em Ciências Agrárias, Universidade Estadual da \\ Paraíba, Rua Baraúnas, 351, Bairro Universitário, Campina Grande, PB, Brazil. Tel: 55-849-8107-8511. E-mail: \\ yurimelo86@gmail.com
}

Received: February 8, 2019

Accepted: March 14, 2019 Online Published: May 15, 2019

doi:10.5539/jas.v11n6p171

URL: https://doi.org/10.5539/jas.v11n6p171

\begin{abstract}
The aim of this study was to determine the concentration and exposure time to $\mathrm{NaCl}$ suitable for the micropropagation of banana, through the analysis of growth traits. Banana propagules were inoculated in MS medium with different concentrations of $\mathrm{NaCl}(0 ; 50 ; 75$ and $100 \mathrm{mM})$ for 120 days (multiplication and rooting, 60 days each), with monthly subcultures. These propagules were measured for plant height, number of leaves, sprouting rate, average number of formed propagules, rooting rate, root length and survival rate. After 30 days, $\mathrm{NaCl}$ reduced sprouting rate at multiplication; the number of leaves, rooting rate and root length in rooting; and the height and propagules number in both phases. After 60 days, the $\mathrm{NaCl}$ affected the sprouting rate and propagules number in the multiplication; length of root in rooting; and the height and number of leaves in both phases. After 120 days, the reduction in the survival rate was proportional to the increase of $\mathrm{NaCl}$ in the medium. Thus, it is concluded that $\mathrm{NaCl}$ reduces most of the growth traits and the treatments with 75 and $100 \mathrm{mM} \mathrm{NaCl}$ affected multiplication and in vitro rooting more intensely.
\end{abstract}

Keywords: in vitro culture, rooting, salt stress, growth traits

\section{Introduction}

Brazil is the third largest fruit producer in the world, with banana cultivation having highest ranking with an average annual production of 6.7 million tons (IBGE, 2017). Banana cultivation is widely exploited in the irrigated perimeters of the Northeast of Brazil and has been expanding in arid and semi-arid regions where soil salinity is associated with low precipitation, high surface evaporation, brackish irrigation and poor cultivation practices.

Around $20 \%$ of total cultivated land and $33 \%$ of irrigated agricultural land is estimated to be affected by high salinity worldwide (Shrivastava \& Kumar, 2015). Soil salinity is one of the main environmental factors that limit global agricultural production (Bessa, Lacerda, Amorim, Bezerra, \& Lima, 2017), interfering with water supply and nutrients which mainly affects the development, growth and survival of plants (Cavalcante, Cordeiro, Nascimento, Cavalcante, \& Dias, 2010).

One of the strategies to overcome the problems caused by salinity is to increase salt tolerance of agricultural species through conventional breeding and/or genetic engineering (Arzani \& Ashraf, 2016). As a result, somaclonal variation associated with in vitro selection pressure has been widely used in breeding programs (Anwar, Kikuchi, \& Watanabe, 2010). Studies with different species show that these techniques are considered viable alternatives in the production of varieties more resistant to salinity (Udomchalothorn, Plaimas, Comai, Buaboocha, \& Chadchawan, 2014) and drought (Maftuchah \& Zainudin, 2015).

Among the main mechanisms used by plants to overcome salinity problems, the accumulation of compatible solutes act as osmoprotective compounds and contribute to osmotic adjustment, helping to resistance of plants under stress conditions (Bundig et al., 2017). Proline is one of the main osmoprotectants that acts on membrane 
stabilization and avoids the degradation of proteins under stress conditions, playing an important role in the osmotic adjustment (Farooq, Wahid, Kobayashi, \& Fujita, 2009).

Due to large declines in productivity in salinised areas, research has been done in the search for genotypes that are more resistant to salinity and, in the specific case of bananas, that improve characteristics to those that are already genetically resistant to pests, such as Caipira (AAA), which is resistant to yellow sigatoka, black sigatoka, rhizome-borer and panama disease (Ramos, M. Leonel, \& S. Lenoel, 2009).

Especially in banana cultivation, the use of micropropagated seedlings is of great importance in production systems, mainly due to rapid multiplication which guarantees the physiological, genetic, phytosanitary and uniformity of the crop (Oliveira, Pereira, Nietsche, Soouza, \& Costa, 2014). However, before performing in vitro selection, it is necessary to identify the degree of resistance of the species when subjected to the stress factors, which determines the doses of the selected agent to be added to the culture medium.

Studies carried out with in vitro grown diploid genotypes of banana showed that the presence of $\mathrm{NaCl}$ in the culture medium significantly reduced the number of leaves, height, pseudocaule diameter and leaf area, and also the fresh and dry phytomass of both shoots as well as the root portion (Silva et al., 2009). In addition, in bananas of the Nanicão cultivar (Musa spp. AAA), a concentration of $120 \mathrm{mM} \mathrm{NaCl}$ reduced the number and size of the buds and the regeneration rate of plants in vitro (Ulisses et al., 2000). With the Grand Naine cultivar, the increase in saline levels in in vitro cultivation significantly reduced leaf length, umber of leaves, fresh matter yield, shoot number and bud survival rate (Macêdo et al., 2005). Although the study was carried out on the banana tree, the studied cultivars and the doses of $\mathrm{NaCl}$ used were different from those used by Ulisses et al. (2000) and Silva et al. (2009), thus showing that the in vitro response is to cultivar- and dose-dependent. Therefore it is necessary to carry out preliminary studies to determine the dose of $\mathrm{NaCl}$ added to the culture medium.

Thus, the objective of this study was to determine a $\mathrm{NaCl}$ concentration, and a duration of exposure to salt, suitable for studies involving micropropagation of the banana cv. Caipira, with an emphasis on characterising the effects of salinity on growth, water status and osmotic adjustment indicators.

\section{Method}

Propagules of banana (Musa spp. cv. Caipira), from the germplasm of the Empresa de Pesquisa Agropecuária do Rio Grande do Norte (EMPARN-Jiqui), with an average age of two months, were obtained in vitro. The study was divided in two stages that comprise the micropropagation, one referred to as multiplication and the second as the rooting stage.

During the multiplication phase, two-month-old defoliated banana propagules measuring approximately $1.0 \mathrm{~cm}$ were inoculated in MS medium (Murashige \& Skoog, 1962) supplemented with $200 \mathrm{mg} \mathrm{L}^{-1}$ of inositol, $30 \mathrm{~g} \mathrm{~L}^{-1}$ of sucrose, $4.5 \mathrm{mg} \mathrm{L}^{-1}$ of 6-Benzylaminopurine (BAP), and containing different concentrations of $\mathrm{NaCl}(0 \mathrm{mM}$ for the control; 50, 75 and $100 \mathrm{mM}$ ). The medium was solidified with $2 \mathrm{~g} \mathrm{~L}^{-1}$ of Phytagel ${ }^{\mathrm{TM}}$ and the $\mathrm{pH}$ adjusted to 5.7. The flasks, containing $40 \mathrm{~mL}$ of the nutrient medium, were sterilised for $20 \mathrm{~min}$ at $1.5 \mathrm{~atm}$ and then the propagules were inoculated in the different saline treatments. Twenty-five propagules were distributed per treatment, and one seedlot per inoculum was inoculated, totaling 100 experimental units. The flasks containing the propagules were kept in a growth room at a temperature of $25 \pm 5^{\circ} \mathrm{C}$, light intensity of $30 \mu \mathrm{mol} \mathrm{m} \mathrm{m}^{-2} \mathrm{~s}^{-1}$ and a 12/12 hours (light/dark) photoperiod for 60 days.

The propagules were subcultured every 30 days under aseptic laminar flow hood conditions and evaluated for height, leaf number, sprouting rate [(seedlings/inoculated seedlings $) \times 100]$ and the mean number of seedlings formed (total of propagules formed/number of propagules that formed new propagules). After 60 days in multiplication medium, the propagules were transferred to the rooting medium with half of the nutrients available in the MS solution and supplemented with $100 \mathrm{mg} \mathrm{L}^{-1}$ of inositol and $15 \mathrm{~g} \mathrm{~L}^{-1}$ of sucrose. In the middle of the rooting period, the same concentrations of $\mathrm{NaCl}(0,50,75$ and $100 \mathrm{mM})$ were added and the medium was solidified with $2 \mathrm{~g} \mathrm{~L}^{-1}$ Phytagel $^{\mathrm{TM}}$ (pH 5.7). The propagules remained for a further 60 days in the rooting medium under the same environmental conditions described above. After 30 days, new subcultures were performed, with growth analysis (height and number of leaves of the propagules, sprouting rate, average number of propagules formed, and rooting rate [(inoculated plant/root propagating plant) $\times 100]$ ). At the end of the 120 days of the micropropagation stages, the survival rate of the initially inoculated propagules was calculated.

After 120 days of micropropagation, the banana propagules were divided into leaves and roots and both parts were evaluated for water status indicators, represented by relative water content (RWC) and humidity (H), in addition to the occurrence of electrolyte leakage (EL) and osmotic adjustment indicators, namely concentrations of total soluble sugars (TSS), total free amino acids (TFAA) and proline (PRO). 
In order to verify the RWC, fresh mass (FM), turgid mass (TM) and dry mass (DM) were determined for shoots and roots of each propagule. These values were included in the following mathematical expression of Irigoyen, Emerich and Sanchez-Diaz (1992): RWC $(\%)=($ FM-DM/TM-DM $) \times 100$. The percentage humidity was determined according to Slavick (1974) using the following equation: $\mathrm{H}(\%)=[(\mathrm{FM}-\mathrm{DM}) / \mathrm{FM}] \times 100$.

The EL was estimated according to Blum and Ebercon (1981). The aerial and root portions were soaked in deionised water at room temperature $\left(25 \pm 5^{\circ} \mathrm{C}\right)$ for six hours with occasional stirring. After this period, the first reading of the electrical conductivity of the bottled solution $\left(\mathrm{L}_{1}\right)$ was established. Subsequently, the plant materials were heated in a water bath at $100{ }^{\circ} \mathrm{C}$ for 1 hour and cooled to room temperature to perform the second reading $\left(\mathrm{L}_{2}\right)$ of EL. The EL $(\%)$ was determined using the equation: $\mathrm{EL}(\%)=\left(\mathrm{L}_{1} / \mathrm{L}_{2}\right) \times 100$.

Levels of total soluble sugars (TSS) were determined by spectrophotometry using the phenol-sulphuric acid method described by Dubois, Gilles, Hamilton, Rebers, and Smith (1956). Concentrations of TSS were determined using a standard curve that was constructed using D-glucose, with absorption measured at $490 \mathrm{~nm}$. Results were expressed as $\mu \mathrm{mol} \mathrm{g} \mathrm{g}^{-1}$ dry mass. The concentration of total free amino acids (TFAA) was determined according to the method described by Peoples, Faizah, Reakasem, and Herridge (1989), where TFAA concentrations were determined using a standard curve that was constructed using L-glutamine, with absorption measured at $570 \mathrm{~nm}$. Results were expressed as $\mu \mathrm{mol} \mathrm{g}^{-1}$ dry mass. The concentration of Proline (PRO) was determined according to a methodology described by Bates (1973), where the concentrations of PRO were determined using a standard curve that was constructed using L-proline, with absorption measured at $520 \mathrm{~nm}$ and results were expressed as $\mu \mathrm{mol} \mathrm{g}^{-1}$ dry mass.

The experimental design used for the growth variables was a completely randomised design with four saline treatments (0-control, 50, 75 and $100 \mathrm{mM} \mathrm{NaCl})$ and 25 replicates for each exposure time, both in the multiplication phase and in the rooting phase. The samples for three saline treatments ( 0 -control, 50 and $100 \mathrm{mM}$ $\mathrm{NaCl}$ ), with five replicates for each organ evaluated (leaf and root), were used to determine water status, EL and osmoregulators.

The data were submitted to analysis of variance (F test) and the means for each exposure time were compared by the Tukey test at the 5\% probability level using Assistat statistical program (version 7.7 beta).

\section{Results and Discussion}

In the in vitro multiplication and rooting phases, the addition of $\mathrm{NaCl}$ to the culture medium caused a significant reduction in the growth of banana (Musa spp. cv. Caipira) plants as indicated by the height, root length, average number of live leaves, sprouting rate and rooting of propagules (Figure 1).

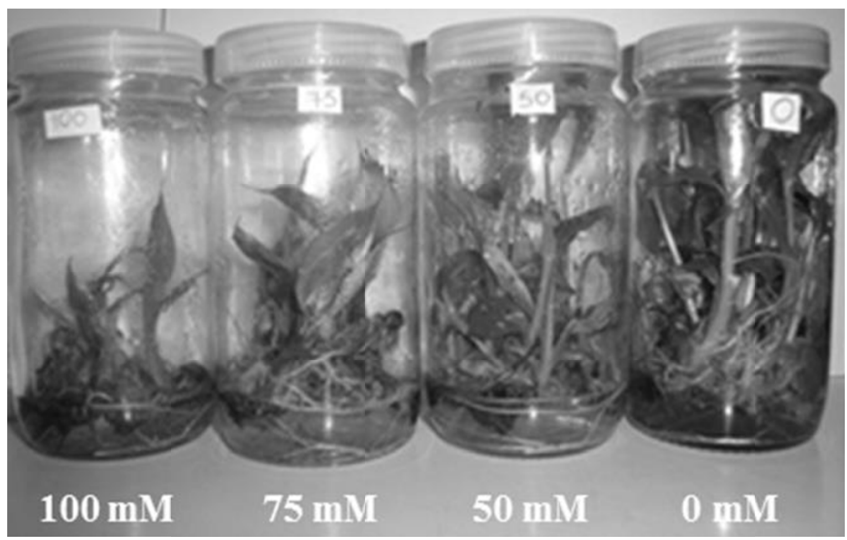

Figure 1. Bananeira Musa spp. cv. Caipira after 120 days of in vitro culture in the absence (control) and presence of different concentrations of $\mathrm{NaCl}(50,75$ and $100 \mathrm{mM})$

In the multiplication phase and with 30 days of stress, the propagules cultivated in the presence of $\mathrm{NaCl}$ grew less in relation to the control. This effect was significant and directly proportional to the increase in salt dose. In the presence of $100 \mathrm{mM} \mathrm{NaCl}$, there was a more than $50 \%$ reduction in height of the propagules compared to those cultivated in the absence of $\mathrm{NaCl}(0 \mathrm{mM}$-control). From 60 days, the height of the propagules cultivated with 75 and $100 \mathrm{mM} \mathrm{NaCl}$ showed a reduction of approximately $27 \%$ and $69 \%$, respectively, compared to the control (Figure 2A). Such response is probably related to the osmotic component and/or the ionic component of 
the salinity (Kader \& Lindberg, 2010). Similar results have been reported for other species, such as pineapple (Melo et al., 2011) and rice (Theerawitaya et al., 2015), when cultivated in vitro and in the presence of $\mathrm{NaCl}$. The high concentration of $\mathrm{Na}^{+}$and $\mathrm{Cl}^{-}$ions can cause disruption in water homeostasis and ionic imbalance, thus promoting toxic effects in plant and consequently affecting plant growth (Tavakkoli et al., 2011).
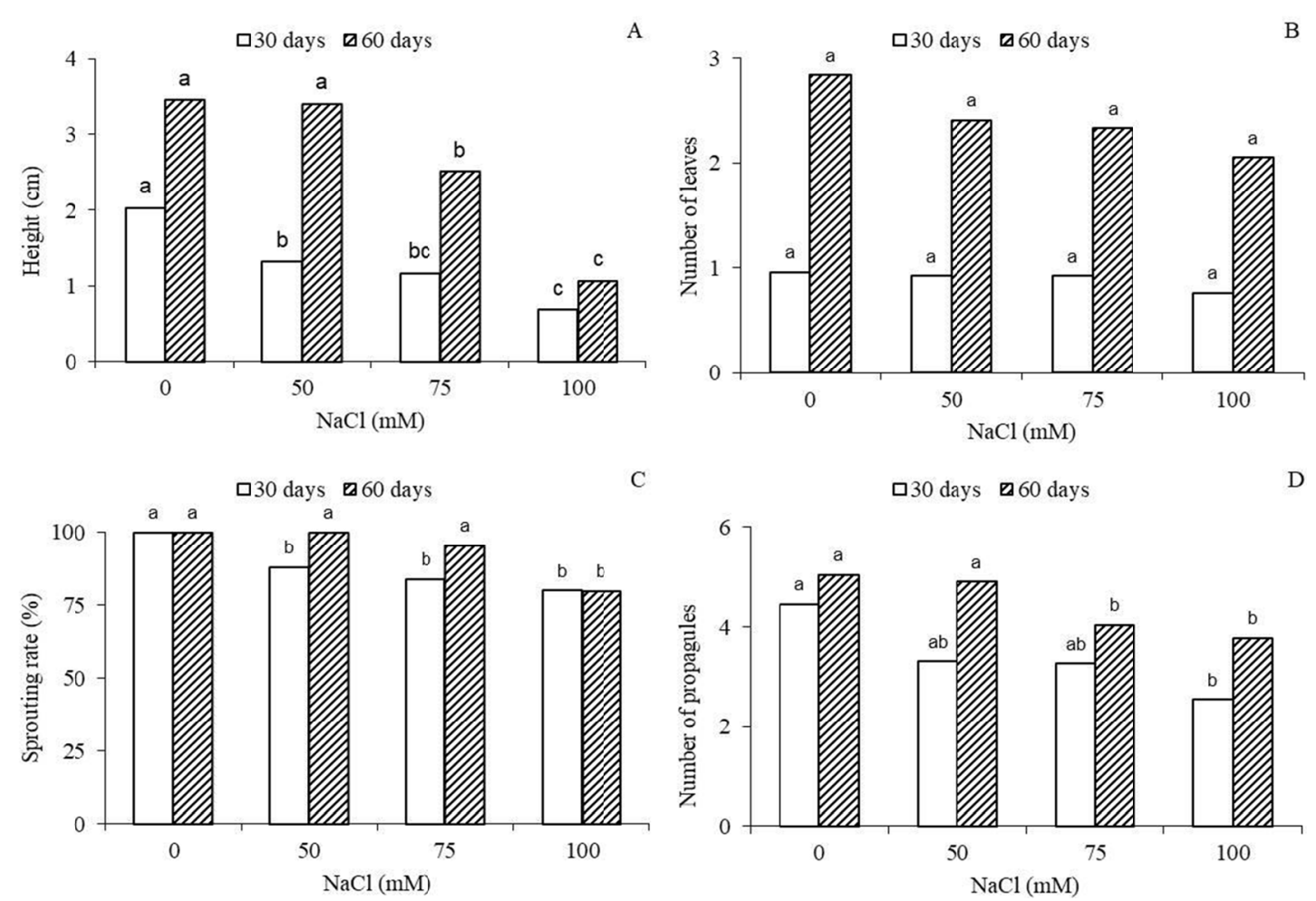

Figure 2. Height (A), number of leaves (B), sprouting rate (C) and shoot number (D) of banana propagules Musa spp. cv. Caipira in absence (control) and presence of 50,75 and $100 \mathrm{mM} \mathrm{NaCl}$ for 30 and 60 days of multiplication. Means followed by the same letter at each exposure time do not differ significantly from each other by the Tukey test at the $5 \%$ probability level

The addition of $\mathrm{NaCl}$ in the culture medium did not affect the vegetative growth as indicated by the number of leaves during the first 30 days of stress in the multiplication phase (Figure 2B). However, in the 60-day period, the number of leaves decreased with increasing $\mathrm{NaCl}$ dose. At the highest dose of $\mathrm{NaCl}(100 \mathrm{mM})$, although there was no significant difference, the decrease was approximately $27 \%$ when compared to the control. Such a decrease can be explained by a delay and/or inhibition in the production of new leaves and shoots. According to Zhu (2001), the delay in the development of plants under saline stress may be due to low osmotic potential of the solution, nutritional imbalance, ion-specific effect or a combination of these.

At 30 days of cultivation, in the absence of salt ( $0 \mathrm{mM}$-control), the propagules reached a budding rate of $100 \%$ (Figure 2C). However, in the presence of $\mathrm{NaCl}$, the capacity to regenerate new propagules was reduced. In the first 30 days, with all $\mathrm{NaCl}$ concentrations, the reduction in sprouting rate ranged from $80 \%$ to $88 \%$. Interestingly, at 60 days of cultivation, sprouting rates in propagules grown in the presence of 50 and $75 \mathrm{mM} \mathrm{NaCl}$ increased by $100 \%$ and $95 \%$, respectively, whereas those grown in $100 \mathrm{mM}$ did not regenerate new propagules (Figure 2C). These results suggest that $\mathrm{NaCl}$ at moderate doses $(50$ and $75 \mathrm{mM})$ delays the regeneration of new propagules and at high doses $(100 \mathrm{mM})$ partially inhibits such regeneration. Similar results were observed in banana cv. Grand Naine (Macêdo et al., 2005) and in pineapple cv. MD Gold (Melo et al., 2011).

After 30 and 60 days of exposure to stress, the salt reduced the average number of propagules formed/buds inoculated compared to the control. This decrease was significantly higher in the $100 \mathrm{mM} \mathrm{NaCl}$ dose (42\%) and there was no significant difference between the control, $50 \mathrm{mM}$ and $75 \mathrm{mM} \mathrm{NaCl}$ treatments after 30 days in the multiplication phase. After 60 days and in the presence of 75 and $100 \mathrm{mM} \mathrm{NaCl}$, the reduction was approximately $25 \%$ in relation to the control (Figure 2D). The gradual increase in $\mathrm{NaCl}$ concentration makes water less available to the plant, reducing turgor and, consequently, growth due to a decrease in cell division and 
stretching (Skirycz \& Inzé 2010). Similar results were observed in the banana cultivars Grand Naine (Macêdo et al., 2005), Nanicão, Pacovan, IAC, Calcutta-4, Microcarpa, Borneo, Jaribuaia and S/N.2 (Carvalho et al., 2006), and in the pineapple var. Smooth Cayenne (Brito et al., 2007) and cv. MD Gold (Melo et al., 2011). Damage caused by salt stress includes delay, inhibition or atrophy in the appearance of the gems, being a common effect in the vegetables exposed to salt (Macêdo et al., 2005).

In relation of rooting, in the presence of $\mathrm{NaCl}$, the growth of the propagules, evaluated by height, in both 30 and 60 days, were lower than the control group. This effect was more pronounced at higher concentrations of $\mathrm{NaCl}$, with more than $62 \%$ reduction in the height of the propagules at $100 \mathrm{mM} \mathrm{NaCl}$ (Figure 3A). It is probable that the salt negatively affected the flow of water near the propagules, due to a reduction in the water permeability of the medium and in the hydraulic conductivity. As a result, the permeability of the cell membranes and the water inflow to the propagules are reduced (Kaneko et al., 2015). Due to these factors, cell expansion and cell division can be reduced by the accumulation of salts in the cell wall and in the protoplasm, which can reduce turgor and consequently growth, because saline stress reduces the activity of cyclin-dependent protein kinases which participate in the cell cycle (Macêdo et al., 2005).
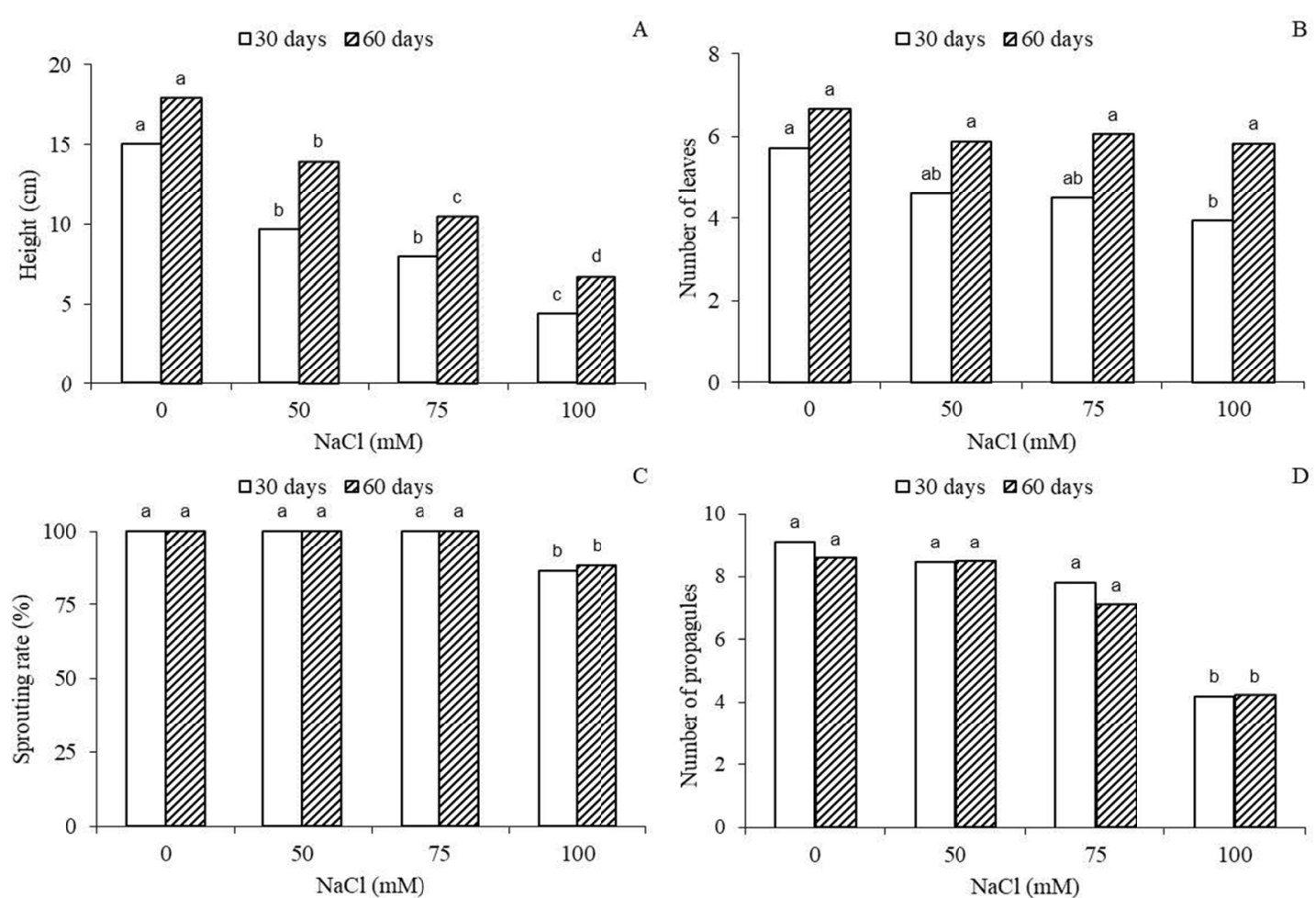

Figure 3. Height (A), number of leaves (B), sprouting rate (C) and number of shoots (D) of banana propagules Musa spp. cv. Caipira during 30,60 days of rooting, in absence (control) and presence of 50;75 and $100 \mathrm{mM}$ $\mathrm{NaCl}$. Means followed by the same letter at each exposure time do not differ statistically from each other by the Tukey test at the $5 \%$ probability level

At 30 and 60 days of exposure to $\mathrm{NaCl}$, there was a reduction in the number of leaves in the saline treatments. This effect was independent of the dose and time of exposure to $\mathrm{NaCl}$. There was a reduction of approximately $24 \%$ and $12 \%$ at 30 and 60 days, respectively, relative to their respective controls (Figure 3B). The decrease in the production of live leaves may be related to the effect of salt, which reduces the ability of the plants to produce new leaves as fast as their senescence (Muscolo et al., 2003), although it is uncertain whats the death of older leaves by necrosis of their tissues may have potentiated this process. According to Cruz et al. (2003), the accumulation of $\mathrm{Na}^{+}$ions occurs preferentially in the older leaves, probably because it is an adaptive mechanism to protect the apices and leaves which are physiologically more active.

$\mathrm{NaCl}$ reduced the sprouting rate only at $100 \mathrm{mM} \mathrm{NaCl}$ with the two exposure times (30 and 60 days) compared to the respective control groups. With this treatment, after 30 and 60 days, there was a reduction in sprouting rate of $14 \%$ and $12 \%$, respectively. In the control, $50 \mathrm{mM}$ and $75 \mathrm{mM} \mathrm{NaCl}$ treatments, the sprouting rate reached 
100\% after 30 days (Figure 3C). Reductions in sprouting rate were also reported by Melo et al. (2011), studying the in vitro cultivation of pineapple under conditions of saline stress.

Regarding the mean number of propagules formed by inoculated propagules, control and treatment of $50 \mathrm{mM}$ did not present significant differences between the two-time intervals. At 30 days, the presence of 75 and $100 \mathrm{mM}$ $\mathrm{NaCl}$ in the culture medium caused a reduction of $9 \%$ and $51 \%$ in the number of propagules, respectively (Figure 3D). The reduction in the number of propagules with increasing $\mathrm{NaCl}$ concentration in the culture medium can be related to the effect of the salinity on the delay in the appearance and atrophy of the gems, provoked by the reduction in the division and cellular expansion (Brito et al. 2007).

The 30-day rooting rate was reduced by $17 \%$ and $37 \%$ in the presence of 75 and $100 \mathrm{mM} \mathrm{NaCl}$, respectively, with no significant variation between the control and $50 \mathrm{mM} \mathrm{NaCl}$. However, after 60 days, all propagules rooted (Figure 4A).
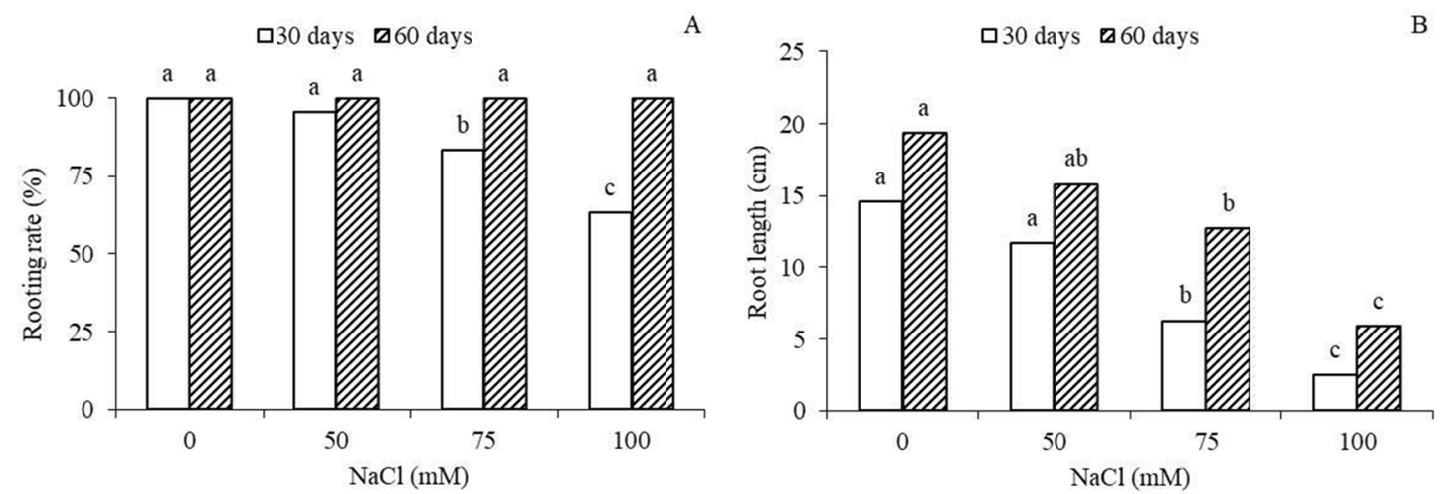

Figure 4. Rooting rate (A) and root length (B) of banana propagules Musa spp. cv. Caipira during 30 and 60 days of rooting, in absence (control) and presence of 50,75 and $100 \mathrm{mM} \mathrm{NaCl}$. Means followed by the same letter at each exposure time do not differ significantly from each other by the Tukey test at the $5 \%$ probability level

With 30 and 60 days of stress exposure, a reduction in the root length of the seedlings in the presence of salt was observed compared to the control. The reduction was significant and directly proportional to the increase in $\mathrm{NaCl}$ concentration in the culture medium (Figure 4B). At 30 and 60 days, and in the presence of $100 \mathrm{mM} \mathrm{NaCl}$, the reduction was $82 \%$ and $70 \%$, respectively.

Both the suppression of the rooting rate in the first 30 days of cultivation and the reduction in the root length of the banana propagules exposed to saline concentrations may be related to the reduction in osmotic potential of the culture medium caused by the presence of $\mathrm{NaCl}$, which makes the water unavailable at optimal levels for the elongation and division of the root cells (Turan, Elkarim, N. Taban, \& S. Taban, 2010).

The survival rate of the propagules under saline conditions decreased significantly with increasing $\mathrm{NaCl}$ concentration in the culture medium (Figure 5). After 120 days and in the presence of $100 \mathrm{mM} \mathrm{NaCl}$, survival was reduced by about $40 \%$ compared to the control. According to Li et al. (2011), the survival rate decreases with increasing salinity in susceptible plants. The increase in $\mathrm{NaCl}$ levels results in the reduction of growth due to several factors, such as the toxic effect of ions that have been absorbed, the low osmotic and water potential of the cells, as well as the use of metabolic energy diverted to other cellular metabolism processes (Lopes, 2015). These changes may affect several metabolic aspects of the plant cell, inducing anatomical and morphological changes that result in reduced growth (Munns, 2008). 


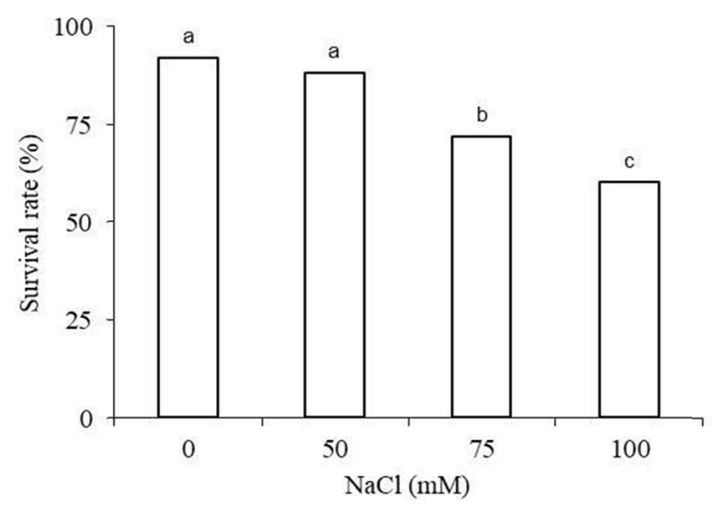

Figure 5. Survival rate of banana propagules Musa spp. cv. Caipira during the stages of multiplication and rooting, after 120 days in the absence (control) and presence of 50, 75 and $100 \mathrm{mM} \mathrm{NaCl}$. Means followed by the same letter do not differ significantly from each other by the Tukey test at the $5 \%$ probability level

After 120 days of micropropagation, no changes in the water status of the propagules were observed in any of the organs studied, independent of the $\mathrm{NaCl}$ concentration (Figures $6 \mathrm{~A}$ and $6 \mathrm{~B}$ ). The propagules maintained a RWC of between $87 \%$ and $93 \%$ in leaves and $90 \%$ and $93 \%$ in roots. The humidity content of the foliar and root tissues of the propagules was maintained at $95 \%$.
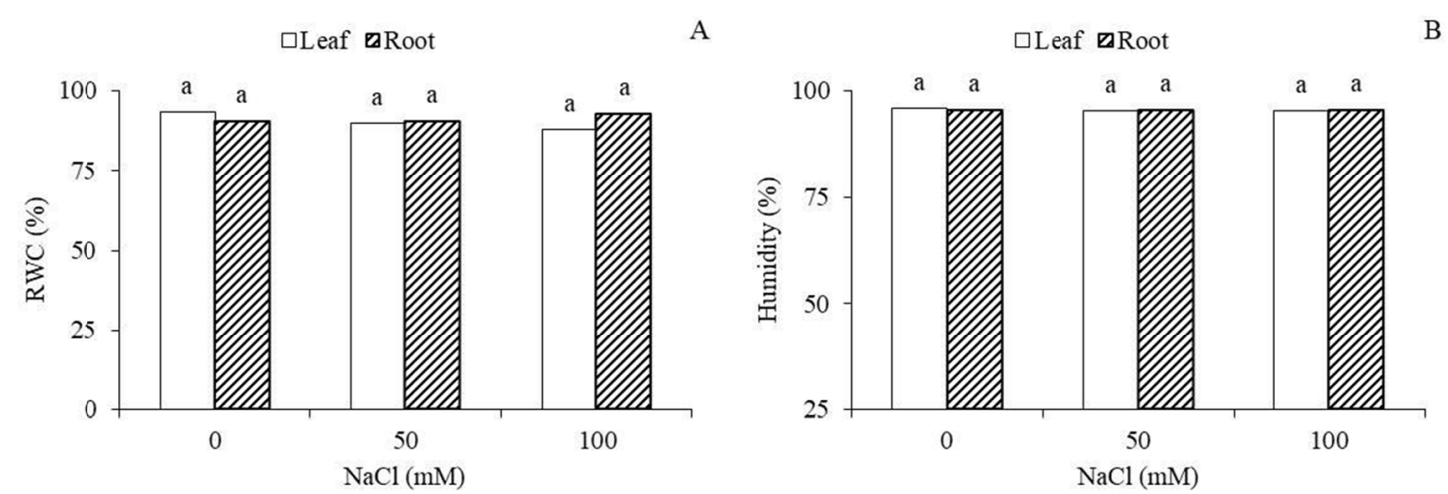

Figure 6. Relative water content (RWC) (A) and humidity (H) (B) of leaves and roots in banana propagules Musa spp. cv. Caipira after 120 days in the absence (control-0 mM) and presence of 50 and $100 \mathrm{mM} \mathrm{NaCl}$. Means followed by the same letter do not differ significantly from each other by the Tukey test at the 5\% probability level

In the present study, the maintenance of the water status of banana propagules may be associated with the presence of sucrose and agar in the nutrient medium, since both substances increase the osmotic potential of the solution (Bundig et al., 2017). In this case, it is possible that the ionic component of saline stress was predominant to the osmotic component of stress. The ionic component of saline stress probably caused the major changes in growth traits in both the multiplication and rooting phases. In addition to causing damage to membranes, high levels of $\mathrm{NaCl}$ probably promoted nutritional imbalances, changes in growth regulator levels, enzymatic inhibitions, disruption of photosynthesis, changes in water relations and ionic imbalance (Khalid, Kumari, Grover, \& Nasim, 2015).

Cell membrane damage, represented by EL, increased as $\mathrm{NaCl}$ increased in the nutrient solution, both in leaves (50 $\mathrm{mM}-41 \%, 100 \mathrm{mM}-120 \%)$ and in roots $(50 \mathrm{mM}-46 \%, 100 \mathrm{mM}-58 \%)$ after 60 days (Figure 7). 


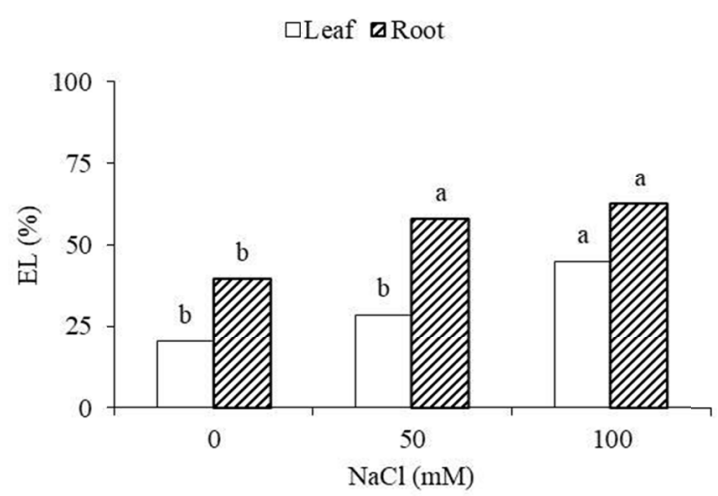

Figure 7. Electrolyte leakage (EL) of leaves and roots in banana propagules Musa spp. cv. Caipira after 120 days in the absence (control- $0 \mathrm{mM}$ ) and presence of 50 and $100 \mathrm{mM} \mathrm{NaCl}$. Means followed by the same letter do not differ significantly from each other by the Tukey test at the $5 \%$ probability level

Possibly the ionic component of saline stress was responsible for the increase in cell membrane damage, both in leaves and roots, as the water status of the cells did not change. In both organs, the excess $\mathrm{Na}^{+}$and $\mathrm{Cl}^{-}$in the protoplasm may have caused disturbances in the ionic balance, which consequently altered the structure of the membranes (Melo et al., 2017). The highest percentages of EL observed in roots, compared to leaves, are probably related to the direct contact between the organ and the saline solution (Melo et al., 2017).

In roots exposed to $100 \mathrm{mM} \mathrm{NaCl}$, an increase of approximately $85 \%$ in total free amino acid levels was observed (Figure 8A). In this same organ, proline levels increased by $74 \%$ and $174 \%$ with $50 \mathrm{mM}$ and $100 \mathrm{mM}$ $\mathrm{NaCl}$, respectively, compared to the control group (Figure 8B).

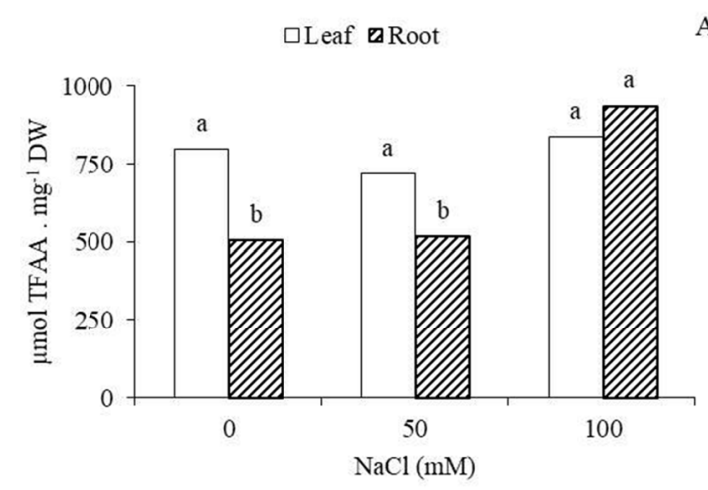

A

$\square$ Leaf $\square$ Root

B

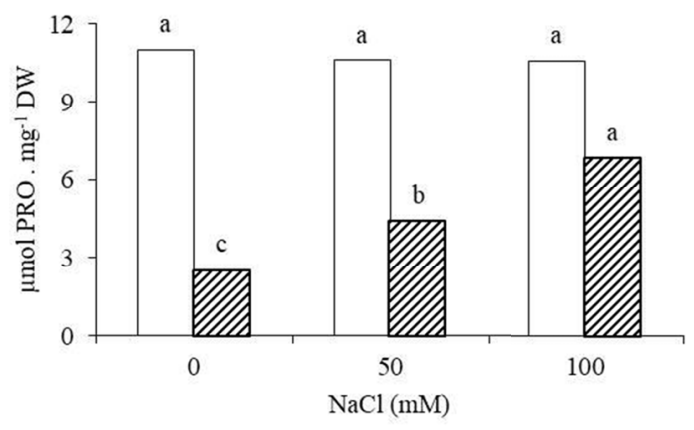

Figure 8. Total free amino acids (TFAA) (A) and proline (PRO) (B) of leaves and roots in banana propagules Musa spp. cv. Caipira after 120 days in the absence (control-0 mM) and presence of 50 and $100 \mathrm{mM} \mathrm{NaCl}$. Means followed by the same letter do not differ significantly from each other by the Tukey test at the 5\% probability level

In leaves, soluble sugar levels increased with saline treatment at $50 \mathrm{mM} \mathrm{NaCl}(33 \%)$ and reduced with $100 \mathrm{mM}$ $\mathrm{NaCl}(15 \%)$ (Figure 9). However, in roots, soluble sugar levels reduced with $50 \mathrm{mM} \mathrm{NaCl}(24 \%)$ and increased with $100 \mathrm{mM} \mathrm{NaCl}$ (73\%) (Figure 9). 


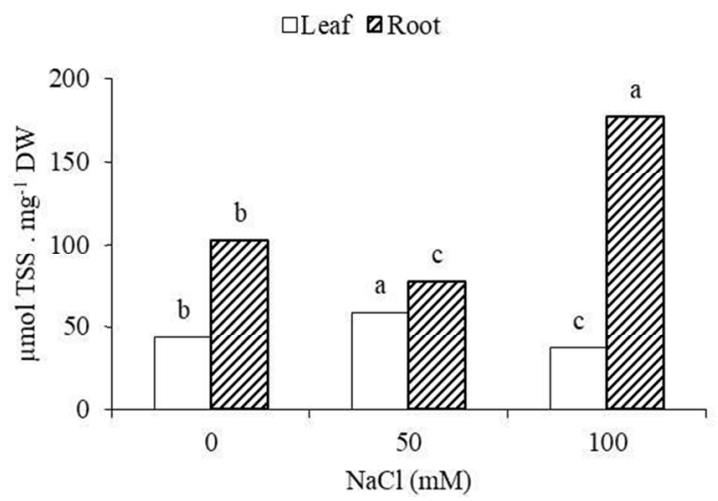

Figure 9. Total soluble sugars (TSS) of leaves and roots in banana propagules Musa spp. cv. Caipira after 120 days in the absence (control- $0 \mathrm{mM}$ ) and presence of 50 and $100 \mathrm{mM} \mathrm{NaCl}$. Means followed by the same letter do not differ statistically from each other by the Tukey test at the $5 \%$ probability level

The accumulation of osmoregulators, such as soluble sugars, amino acids (e.g. proline), inorganic ions and proteins, is commonly associated with osmotic adjustment of plants under stress conditions in order to maintain plant turgor (Joseph et al., 2015).

In the present study, the accumulation of TFAA, PRO, TSS in the roots of seedlings subjected to $100 \mathrm{mM} \mathrm{NaCl}$ may be related to a contribution of such osmoregulators to the maintenance of water status, as it may also be due to changes in protein metabolism, leading to proteolysis and consequently an increase in the levels of TFAA and proline. The increase in proline levels under salt stress conditions, observed only in roots, may be related to the need to use this amino acid in the establishment of this organ during in vitro culture (Bundig et al., 2017). In addition, variations in the levels of organic compounds are also related to disorders in the metabolism of carbohydrates and proteins, and carbon skeletons can be used as an energy source which is easily available to cells under stress conditions, associated with the production of new leaves, formation of new shoots or root growth, observed in the present study (Dkhil \& Denden, 2010; Melo et al., 2017).

\section{Conclusion}

$\mathrm{NaCl}$ caused a reduction in the growth rate which was proportional to the increase in salt concentration. Treatment with 75 and $100 \mathrm{mM} \mathrm{NaCl}$ affected multiplication, rooting and in vitro growth more intensely than the control. The ionic component of salinity seems to be the main cause of damage to the development of banana propagules grown in vitro, mainly as a result of damage to cell membranes. The variations in the osmolytes evaluated appear to be related to $\mathrm{NaCl}$ disturbances to plant metabolism rather than an attempt by the propagules to osmotically adjust. In addition, it is recommended that treatment with $100 \mathrm{mM} \mathrm{NaCl}$ for a minimum of 30 days is used for in vitro intensified saline stress tests in banana cv. Caipira.

\section{Acknowledgements}

The authors thank the financial support received from the Empresa de Pesquisa Agropecuária do Rio Grande do Norte (EMPARN), Empresa Brasileira de Pesquisa Agropecuária (EMBRAPA), Universidade Federal do Rio Grande do Note (UFRN) and Coordenação de Aperfeiçoamento de Pessoal de Nível Superior (CAPES).

\section{References}

Anwar, N., Kikuchi, A., \& Watanabe, K. N. (2010). Assessment of somaclonal variation for salinity tolerance in sweet potato regenerated plants. African Journal of Biotechnology, 9, 7256-7265. https://doi.org/10.5897/ AJB09.1229

Arzani, A., \& Ashraf, M. (2016). Smart engineering of genetic resources for enhanced salinity tolerance in crop plants. Critical Reviews in Plant Science, 35, 146-189. https://doi.org/10.1080/07352689.2016.1245056

Bates, L. S., Waldren, R. P., \& Teare, I. D. (1973). Rapid determination of free proline for 4159 water-stress studies. Plant and Soil, 39, 205-207. https://doi.org/10.1007/BF00018060

Bessa, M. C., Lacerda, C. F., Amorim, A. V., Bezerra, A. M. E., \& Lima, A. D. (2017). Mechanisms of salt tolerance in seedlings of six woody native species of the Brazilian semi-arid. Revista Ciência Agronômica, 48, 157-165. https://doi.org/10.5935/1806-6690.20170018 
Blum, A., \& Ebercon, E. (1981). Cell membrane stability as a measure of drought and heat tolerance in wheat. Crop Science, 21, 43-47. https://doi.org/10.2135/cropsci1981.0011183X002100010013x

Brito, L. K. F. L., Moura, G. E. D. D., Martins, C. P., Aloufa, M. A. I., Macêdo, C. E. C., Lopes, D. B., \& Barroso, P. A. V. (2007). Cultivo in vitro de somaclones de abacaxizeiro na presença de $\mathrm{NaCl}$. Revista Brasileira de Engenharia Agricola e Ambiental, 11, 279-283. https://doi.org/10.1590/S1415-436620070 00300006

Bündig, C., Vu, T. H., Meise, P., Seddig, S., Schum, A., \& Winkelmann, T. (2017). Variability in osmotic stress tolerance of starch potato genotypes (Solanum tuberosum L.) as revealed by an in vitro screening: Role of proline, osmotic adjustment and drought response in pot trials. Journal of Agronomy and Crop Science, 203, 206-218. https://doi.org/10.1111/jac.12186

Carvalho, J. S. B., Willadino, L. G., Camara, T. R., Porto, A. L. F., \& Nogueira, R. J. M. C. (2006). Acúmulo de solutos orgânicos em genótipos de bananeira (Musa spp.) sob estresse salino in vitro. Plant Cell Culture \& Micropropagation, 2, 1-8. Retrieve from http://www.abctp.ufla.br/v2n1.pdf

Cavalcante, L. F., Cordeiro, J. C., Nascimento, J. A. M., Cavalcante, I. H. L., \& Dias, T. J. (2010). Fontes e níveis da salinidade da água na formação de mudas de mamoeiro cv. Sunrise solo. Semina: Ciências Agrárias, 31, 1281-1290. https://doi.org/10.5433/1679-0359.2010v31n4Sup1p1281

Cruz, J. L., Pelacani, C. R., Soares-Filho, W. S., Castro-Neto, M. T., Coelho, E. F., Dias, A. T., \& Paes, R. A. (2003). Produção e partição de matéria seca e abertura estomática do limoeiro 'cravo' submetido a estresse salino. Revista Brasileira de Fruticultura, 25, 528-531. https://doi.org/10.1590/S0100-29452003000300042

Dkhil, B. B., \& Denden, M. (2010). Salt stress induced changes in germination, sugars, starch and enzyme of carbohydrate metabolism in Abelmoschus esculentus L. (Moench.) seeds. African Journal of Agricultural Research, 5, 1412-1418.

Dubois, M., Gilles, K. A., Hamilton, J. K., Rebers, P. A., \& Smith, F. (1956). Colorimetric 4194 Method for determination of sugars and related compounds. Analytical Chemistry, 28, 350-356. https://doi.org/10.1021/ ac60111a017

Farooq, M., Wahid, A., Kobayashi, N., Fujita, D., \& Basra S. M. A. (2009). Plant drought stress: Effects, mechanisms and management. Agronomy for Sustainable Development, 29, 185-212. https://doi.org/ 10.1051/agro:2008021

IBGE (Instituto Brasileiro de Geografia e Estatística). (2017). Levantamento sistemático da produção agrícola: pesquisa mensal de previsão e acompanhamento das safras agrícolas no ano civil. Rio de Janeiro: Instituto Brasileiro de Geografia e Estatística.

Irigoyen, J. J., Emerich, D. W., \& Sanchez-Diaz, M. (1992). Water stress induced changes in concentrations of proline and total soluble sugars in nodulated alfalfa (Medicago sativa) plants. Physiologia Plantarum, 84, 55-60. https://doi.org/10.1111/j.1399-3054.1992.tb08764.x

Joseph, E. A., Radhakrishnan, V. V., \& Mohanan, K. V. (2015). A Study on the accumulation of proline-An osmoprotectant amino acid under salt stress in some native rice cultivars of North Kerala, India. Universal Journal of Agricultural Research, 3, 15-22. https://doi.org/10.13189/ujar.2015.030104

Kader, M. A., \& Lindberg S. (2010). Cytosolic calcium and pH signaling in plants under salinity stress. Plant Signaling \& Behavior, 5, 233-238. https://doi.org/10.4161/psb.5.3.10740

Kaneko, T., Horie, T., Nakahara, Y., Tsuji, N., Shibasaka, M., \& Katsuhara, M. (2015). Dynamic regulation of the root hydraulic conductivity of barley plants in response to salinity/osmotic stress. Plant Cell Physiology, 56, 875-882. https://doi.org/10.1093/pcp/pcv013

Khalid, H., Kumari, M., Grover, A., \& Nasim, M. (2015). Salinity stress to lerance of camelina investigated in vitro. Scientia Agriculturae Bohemica, 46, 137-144. https://doi.org/10.1515/sab-2015-0028

Li, H. W., Zang, B. S., Deng, X. W., \& Wang, X. P. (2011). Overexpression of the trehalose-6-phosphate synthase gene OsTPS1 enhances abiotic stress tolerance in rice. Planta, 234, 1007-1018. https://doi.org/ $10.1007 / \mathrm{s} 00425-011-1458-0$

Lopes, M. C. S. (2015). Incremento de potássio em plantas de girassol (Helianthus annuus L.) submetidas ao estresse salino. Mossoró: Universidade Federal Rural do Semi-Árido. Retrieve from https://ppgfito.ufersa. edu.br/wp-content/uploads/sites/45/2015/02/Disserta\%C3\%A7\%C3\%A3o-2015-MONIQUE-CRISTINA-SI M\%C3\%83O-LOPES.pdf 
Macêdo, C. E. C., Barroso, P. A. V., Moura, G. E. D. D., \& Alloufa, M. A. I. (2005). Efeito do NaCl sobre o crescimento e a multiplicação in vitro de bananeira. Revista Brasileira de Fruticultura, 27, 194-197. https://doi.org/10.1590/S0100-29452005000200003

Maftuchah, Zainudin, A. (2015). In vitro selection of Jatropha curcas Linn. hybrids using polyethylene glycol to obtain drought tolerance character. Procedia Chemistry, 14, 239-245. https://doi.org/10.1016/j.proche. 2015.03.034

Melo, Y. L., Dantas, C. V. S., Lima-Melo, Y., Maia, J. M., \& Macêdo, C. E. C. (2017). Changes in osmotic and ionic indicators in Ananas comosus (L.) cv. MD Gold pre-treated with phytohormones and submitted to saline medium. Revista Brasileira de Fruticultura, 39, 1-14. https://doi.org/10.1590/0100-29452017155

Melo, Y. L., Gomes, I. A., Dantas, C. V. S., Brito, L. K. F., Oliveira, M. D. M., \& Macêdo, C. E. C. (2011). Indicadores de estresse salino em abacaxizeiro cultivado na ausência e presença de fitorreguladores. Revista Brasileira de Fruticultura, 33, 698-705. https://doi.org/10.1590/S0100-29452011005000104

Munns, R., \& Tester, M. (2008). Mechanisms of salinity tolerance. Annual Review of Plant Biology, 9, 651-681. https://doi.org/10.1146/annurev.arplant.59.032607.092911

Murashige, T., \& Skoog, F. (1962). A revised medium for rapid growth and bio assays with tobacco tissue cultures. Physiologia Plantarum, 15, 473-497. https://doi.org/10.1111/j.1399-3054.1962.tb08052.x

Muscolo, A., Panuccio, M. R., \& Sidari, M. (2003). Effects of salinity on growth, carbohydrate metabolism and nutritive properties of kikuyu grass (Pennisetum clandestinum Hoscht). Plant Science, 164, 1103-1110. https://doi.org/10.1016/S0168-9452(03)00119-5

Oliveira, J. A. A., Pereira, M. C. T., Nietsche, S., Souza, V. N. R., \& Costa, I. J. S. (2014). Aclimatização de mudas micropropagadas de bananeira em diferentes substratos e recipientes. Revista Brasileira de Ciências Agrárias, 9, 72-78. https://doi.org/10.5039/agraria.v9i1a3682

Peoples, M. B., Faizah, A. W., Reakasem, B., \& Herridge, D. F. (1989). Methods for 4318 evaluating nitrogen fixation by nodulated legumes in the field. Camberra: International Center of Agricultural Research.

Ramos, D. P., Leonel, M., \& Leonel, S. (2009). Amido resistente em farinhas de banana verde. Alimentos $e$ Nutrição, 20, 479-483.

Shrivastava, P., \& Kumar, R. (2015). Soil salinity: A serious environmental issue and plant growth promoting bacteria as one of the tools for its alleviation. Saudi Journal of Biological Sciences, 22, 123-131. https://doi.org/10.1016/j.sjbs.2014.12.001

Silva, R. L. O., Martins, L. S. S., Gomes, E. W. F., Ferraz, G. M. G., Silva, S. O., \& Willadino, L. (2009). Avaliação de diploides de bananeira (Musa spp.) quanto à tolerância a salinidade. Revista Brasileira de Fruticultura, 31, 1084-1091. https://doi.org/10.1590/S0100-29452009000400023

Skirycz, A., \& Inze, D. (2010). More from less: Plant growth under limited water. Current Opinion in Biotechnology, 21, 197-203. https://doi.org/10.1016/j.copbio.2010.03.002

Tavakkoli, E., Fatehi, F., Coventry, S., Rengasamy, P., \& Mcdonald, G. K. (2011). Additive effects of $\mathrm{Na}^{+}$and $\mathrm{Cl}^{-}$ ions on barley growth under salinity stress. Journal of Experimental Botany, 62, 2189-2203. https://doi.org/10.1093/jxb/erq422

Theerawitaya, C., Yamada, N., Samphumphuang, T., Cha-Um, S., Kirdmanee, C., \& Takabe, T. (2015). Evaluation of $\mathrm{Na}^{+}$enrichment and expression of some carbohydrate related genes in indica rice seedlings under salt stress. Plant Omics Journal, 8, 130-140.

Turan, M. A., Elkarim, A. H. A., Taban, N., \& Taban, S. (2010). Effect of salt stress on growth and ion distribution and accumulation in shoot and root of maize plant. African Journal of Agricultural Research, 5, 584-588. https://doi.org/10.5897/AJAR09.677

Udomchalothorn, T., Plaimas, K., Comai, L., Buaboocha, T., \& Chadchawan, S. (2014). Molecular karyotyping and exome analysis of salt-tolerant rice mutant from somaclonal variation. The Plant Genome, 7, 1-11. https://doi.org/10.3835/plantgenome2014.04.0016

Ulisses, C., Câmara, T. R., Willadino, L., Meunier, I., \& Rocha, P. S. G., Albuquerque, C. (2000). Seleção in vitro de gemas de bananeira "Nanicão" resistentes à salinidade. Scientia Agricola, 57, 667-670. https://doi.org/10.1590/S0103-90162000000400011 
Zhu, J. K. (2001). Cell signaling under salt, water and cold stresses. Current Opinion in Plant Biology, 4, 401-406. https://doi.org/10.1016/S1369-5266(00)00192-8

\section{Copyrights}

Copyright for this article is retained by the author(s), with first publication rights granted to the journal.

This is an open-access article distributed under the terms and conditions of the Creative Commons Attribution license (http://creativecommons.org/licenses/by/4.0/). 